\title{
SECTION: MEDICAL PSYCHOLOGY
}

РОЗДІЛ: МЕДИЧНА ПСИХОЛОГІЯ

UDC 159.931-937:159.9.07:159.964.22-092.9

DOI: $10.26565 / 2410-1249-2020-14-04$

\section{РОЗРОБКА І АПРОБАЦІЯ ЕКСПЕРИМЕНТАЛЬНО-ПСИХОЛОГІЧНИХ МЕТОДИК ДЛЯ ДОСЛІДЖЕННЯ НЕУСВІДОМЛЮВАНИХ ЗОРОВО-ПЕРЦЕПТИВНИХ ПРОЦЕСІВ}

\author{
ФШестопалова Л.Ф. \\ Державна установа «Інститут неврології, психіатрії та наркологіі \\ Наџіональної академії медичних наук України» \\ вул. Академіка Павлова, 46, м. Харків, 61068, Украӥна \\ E-mail:6834101@ukr.net,https://orcid.org/0000-0001-6295-0667
}

С Луцик В.Л.

Державна установа «Інститут неврології, психіатрії та наркологіі Національної академії медичних наук України» вул. Академіка Павлова, 46, м. Харків, 61068, Украӥна E-mail: vlaleolu@gmail.com,https://orcid.org/0000-0003-0611-3367

\begin{abstract}
Роботу присвячено актуальній проблемі дослідження зорово-перцептивних процесів, що відбуваються на неусвідомлюваному рівні. Відзначається дефіцит надійного та інформативного психодіагностичного інструментарію, спеціально розробленого i призначеного для дослідження неусвідомлюваних перцептивних і мнестичних феноменів в нормі та у осіб з афективними розладами. Підкреслюється, що при створенні таких методик необхідно враховувати вплив емоційних порушень на перебіг основних психічних процесів. Розроблені три нові експериментально-психологічні методики, спрямовані на дослідження та об'єктивізацію швидкоплинних усвідомлюваних і неусвідомлюваних перцептивноінформаційних процесів. Методика формування субсенсорного стимула полягає в покроковому визначенні точного порогового часу експозиції, при якому один вербальний стимул 3 трьох демонстрованих лишається неідентифікованим на усвідомлюваному рівні, тобто субсенсорним. Методика психофізіологічного підтвердження значущості субсенсорного стимула $є$ автоматизованою реєстраційно-аналітичною процедурою, котра передбачає використання серійного цифрового поліграфа «Реоком-стресс» і дозволяє в множині заданих вербальних стимулів виявити слова, найбільш значущі для даного досліджуваного, незалежно від рівня суб'єктивного усвідомлення цієї значущості. Методика виявлення неусвідомленої перцептивно-мнестичної фіксації субсенсорних стимулів являє собою спосіб дослідження ефекту мимовільного запам'ятовування, ретенції та репродукції субсенсорних стимулів. Апробацію розроблених експериментально-психологічних методик проведено на вибірці з 38 осіб, що включала 23 пацієнта з афективними розладами і 15 психічно здорових осіб. Показано, що пороги зорового сприйняття у хворих на афективні розлади $є$ майже втричі вищими у порівнянні з контрольною групою. Ефект перцептивно-мнестичної фіксації підтверджено однією або декількома методиками у $100 \%$ спостережень. Результати апробації переконливо свідчать про високу чутливість та інформативність використаного підходу.

Ключові слова: експериментально-психологічні методики, візуальне сприйняття, підпорогова перцепція, неусвідомлювані процеси, субсенсорні стимули, мимовільне запам'ятовування, перцептивно-мнестична фіксація.
\end{abstract}

Проблема функціонування неусвідомлюваних психічних процесів є однією з пріоритетних у сучасній психологічній науці в цілому та в медичній психології зокрема. Проте, на теперішний час багато аспектів цієї проблематики залишаються невирішеними. Значною мірою це зумовлено дефіцитом досить надійного експериментально - психодіагностичного інструментарію, спеціально призначеного для дослідження психічних процесів, в тому числі 
перцептивних і мнестичних, що відбуваються на неусвідомлюваному рівні. У різних дослідженнях зазначається, що для об’єктивізації неусвідомлюваних психічних процесів доцільно використовувати різноманітні психофізіологічні показники (особливості біоелектричної активності головного мозку, шкірно-гальванічні реакції, частоти серцевих скорочень та ін.). На сьогодні існує значна кількість апаратних методів, що використовують комплекси психофізіологічних показників для визначення характеру ставлення людини до того чи іншого явища [РеoКом-Stress для Windows XP, 2012)]. Основним недоліком цих методів вважається те, що вони фіксують реакції на усвідомлювану інформацію, в той час як високоінформативні методи оцінки неусвідомлюваних психічних процесів практично відсутні.

Існують вагомі підстави вважати, що процеси візуального сприйняття, - зокрема, підпорогової перцепції, - суттєво відрізняються в нормі та при наявності психічних захворювань, і насамперед це стосується афективних розладів [Шестопалова, 2015, Шестопалова, 2020]. Відомо, що наявність афективних порушень суттєво впливає на протікання усіх психічних процесів, в тому числі на реалізацію когнітивних функцій, що в свою чергу ускладнює як психодіагностичну, так i психокорекційну роботу 3 такими хворими [Maruta, 2020, Шестопалова, 2019]. Недостатньо вивченими також залишаються психофізіологічні кореляти неусвідомлюваних психічних процесів. Разом с тим, використання даних щодо мимовільних, неусвідомлюваних реакцій пацієнтів дозволило б значно підвищити якість діагностики афективних розладів та оптимізувати лікувальнореабілітаційні заходи для цих хворих. Отже, актуальною задачею сучасної медичної психології $\epsilon$ подальший розвиток фундаментального теоретичного

методологічного підгрунтя парадигми неусвідомлюваного, та розробка на цих засадах принципово нових експериментальних технологій, які були б спрямовані саме на дослідження неусвідомлюваних перцептивноінформаційних процесів.
Таким чином, метою дослідження було створення комплексу нових експериментальнопсихологічних методик, призначених для вивчення дослідження неусвідомлюваних зорово-перцептивних процесів, та його апробація для оцінювання особливостей перебігу зазначених процесів у хворих на афективні розлади.

Було обстежено 38 осіб, з них 27 (71,05\%) жінок і 11 (28,95\%) чоловіків. Середній вік складав 43,32 $\pm 12,37$ років. Обстежену вибірку було поділено на дві групи, основну i контрольну. В основну групу увійшли 23 (60,53\%) особи, що страждали на різні форми афективних розладів (за МКX-10 шифри F06.3; F06.31; F06.32; F06.6; F33.1; F33.11; F40.8; F41.2; F48.0). Контрольна група складалася 315 (39,47\%) психічно здорових осіб. За основними соціально-демографічними показниками групи порівняння були гомогенними i відрізнялися лише наявністю/відсутністю психопатологічних розладів.

Зважаючи на загальновідомі уявлення про нерозривні зв'язки мовлення та мислення, семантики стимулів та мимовільного емоційного реагування на них, інформативними можна вважати такі діагностичні методи, що передбачають використання зорових вербальних стимулів в режимі тахістоскопічного пред'явлення, адже у пацієнтів з афективними порушеннями ці процеси досліджені вкрай недостатньо. В свою чергу, одним 3 найперспективніших підходів до вивчення перцептивно-інформаційних процесів неусвідомлюваного рівня уявляється застосування комп'ютеризованих технологій поліграфічної реєстрації та аналізу психофізіологічних показників, які не контролюються свідомістю, проте певним чином змінюються у відповідь на демонстрацію спеціально добраних стимулів.

Обладнання включало: персональний комп'ютер стандартної десктоп-архітектури та конфігурації, 3 двома маніпуляторами «миша» (оскількі передбачалася інтерактивна діяльність досліджуваних) та двома моніторами 3 максимальною частотою оновлення екрану 
120 Гц (120 кадрів на секунду). Остання характеристика була найважливішою, оскільки такий монітор, на відміну від стандартних 60герцевих екранів, дозволяв демонструвати стимули 3 надкороткою експозицією, яка технічно не може бути меншою за тривалість поодинокого кадру. В даному випадку цей показник становив $1 / 120$ секунди, тобто 8,33 мс, - що значно менше пересічних порогів зорового сприйняття людини i, таким чином, забезпечує субсенсорний характер демонстрованих стимулів. Також використовувався апаратно-програмний реографічний комплекс «Реоком» у модифікації «Реоком-стресс» (Свідоцтво про держ. реєстрацію № $\quad$ 6039/2007, паспорт АИНЦ.941311.003 ПС, заводський № 248), що випускається серійно i призначається для реєстрації та автоматизованого аналізу деяких психофізіологічних показників в їхній динаміці [РеоКом-Stress для Windows XP, 2012].

Було створено батарею експериментальнопсихологічних методик, яку склали три нові методики: а) методика формування субсенсорного стимула; б) методика психофізіологічного підтвердження значущості субсенсорного стимула та в) методика виявлення неусвідомлюваної перцептивно-мнестичної фіксації субсенсорних стимулів шляхом пригадування. Призначенням є дослідження та об’єктивізація характеристик швидкоплинних перцептивно-інформаційних процесів, що відбуваються на усвідомлюваному та неусвідомлюваному рівнях.

\section{Методика формування субссенсорного} стимула полягає в покроковому визначенні точного порогового часу експозиції, при якому досліджуваний здатен сприйняти та усвідомити лише два вербальних стимула 3 трьох демонстрованих, тож третій стимул навіть після повторної демонстрації лишається неідентифікованим на свідомому рівні, тобто субсенсорним. Стимульні слова експонували на монотонному синьому тлі, приблизно в центрі екрану, найпростішим шрифтом 3 засічками, чорним кольором. Пред'явлення саме в такому накресленні забезпечує максимально легке розпізнання, найшвидшу аглютинацію літер в слово та ефективне «схоплювання» його значення. Стимулів іншої модальності, а саме звуків, зображень, інтерферуючих візерунків і т. ін., - на екрані не було. Взагалі, на відзнаку від переважної більшості інших досліджень подібної спрямованості [Шестопалова, 2015], в даному випадку не застосовувалися ніякі візуальні «маски», тож режим пред'явлення стимульних слів був суто тахістоскопічним і не містив ніяких штучних перешкод для зорового сприйняття. На нашу думку, цим забезпечувалася чистота проведення експериментальної серії. В якості стимульного матеріалу були застосовані п'ять оригінальних відеофрагментів, створених нами за допомогою програмних засобів нелінійного відеомонтажу. Всі параметри відеофрагментів повністю збігалися: загальна тривалість (прибл. 5 c), пауза перед запуском зворотнього відліку (1 c), тривалість зворотнього відліку (3 с), типорозмір текста і гарнітура шрифта, а також позиція стимулів на екрані (в центрі рамки, що фіксує увагу, але кожного разу 3 незначним непередбачуваним для досліджуваного відхиленням, аби запобігти небажаної передчасної концентрації уваги на точці 3'явлення слів). Відео відрізнялися лише тривалістю експозиції стимулів на екрані: 120, $100,80,60,40$ та 20 кадрів на секунду (відповідно, тривалість поодинокого кадру, тобто час експозиції стимула, складала 8,3 мс, $10,0 \mathrm{mc}, 12,5 \mathrm{mc}, 16,7 \mathrm{mc}, 25,0 \mathrm{мc}$ та $50,0 \mathrm{мc})$. Важливо зазначити, що всі стимульні слова відносилися до загальновживаної лексики і не відрізнялися суттєво за довжиною (згідно 3 результатами пілотажного дослідження, оптимальна довжина слів повинна бути щонайменше 6 , але не перевищувати 8 літер). Склад стимульних серій не повторювався, для кожного досліджуваного це була нова комбінація. Слід також зауважити, що на етапі інструктування досліджуваному демонструвалося ознайомлювальне відео, яке виглядало так само, як і основні стимульні серії, але замість реальних стимульних слів містило просто «Слово1», «Слово2» і «Слово3». Це дозволяло значно знизити рівень тестової 
тривоги, адже досліджуваний на власні очі бачив, що саме відбуватиметься на екрані і якого роду стимули необхідно буде прочитати. Щодо власне стимульних слів, то вони за своїм експліцитним значенням і очевидним емоційним забарвленням чітко розподілялися на три принципово різні категорії: негативну («відчай», «невдача» і т. д.), нейтральну («період», «ситуація» і т. ін.) та позитивну («перемога», «порятунок» і т. п.).

Кінцевою задачею пред'явлення стимульних відеофрагментів було підібрати такий час експозиції стимулів, коли досліджуваний впевнено розпізнає і називає два слова $з$ трьох. Якщо в повторній спробі на цій самій серії досліджуваному також не вдавалося ідентифікувати третє слово, це слово можна було вважати субсенсорним стимулом, - адже воно двічі побувало в центральному полі зору i, попри це, не було розпізнане на свідомому рівні.

\section{Методика}

психофізіологічного підтвердження значущості субсенсорного стимула проводилася безпосередньо після процедури формування субсенсорного стимула $\mathrm{i}$ була спрямована на підтвердження або спростування феномену підпорогового сприйняття в кожному індивідуальному спостереженні. Фактично, порівнювалися неконтрольовані свідомістю психофізіологічні реакції, пов'язані 3 коливаннями споживання кисню організмом, на три типа стимулів:

a) слова, котрі досліджуваний побачив, розпізнав та вголос назвав в попередній методиці (два усвідомлено сприйнятих стимула);

б) шість слів, яких взагалі не було на екрані в попередній методиці («стимули-пустушки»);

в) одне слово, котре досліджуваний запевне бачив щонайменше двічі, але розпізнати та ідентифікувати не встиг (субсенсорний стимул).

Таким чином, в даній методиці об'єктом дослідження були дев'ять вербальних стимулів різного рівня значущості. Інструментом об'єктивної детекції значущості виступав цифровий реографічний реєстратор «Реоком». За допомогою шости стандартних датчиків відстежувалася динаміка 18 низькоамплітудних показників (ЧСС, ударний об'єм кровенаповнення, мимовільний тремор м'язів передпліччя, зміни шкірно-гальванічного потенціалу, особливості пальцевої моторики при натисканні на клавішу, латентний період реакції та ін.). Процедура полягала в тому, що досліджуваний відповідав на дев'ять стереотипних питань, наприклад: «Ви бачили на екрані слово "сторона"?», «Ви бачили на екрані слово "відчай"?» тощо. Кожне питання протягом серії повторювалося п'ять разів, і досліджуваний, згідно 3 інструкцією, кожного разу відповідав «ні», незалежно від того, чи бачив і запам'ятав він певне слово. Очікуваним результатом була різниця між реєстрованою пристроєм психофізіологічною реакцією на слова-стимули, що залишились в пам'яті завдяки підпороговій перцепції, у порівнянні з реакцією на ті слова, котрі досліджуваний побачив, впевнено розпізнав і усвідомив, а також на слова, яких в стимульних відеосеріях не було взагалі. Коливання психофізіологічних показників опрацьовуються програмою в автоматичному режимі, на монітор оператора виводиться крива запису сигналів в режимі реального часу, після чого формується (і за необхідністю зберігається в накопичувальній базі даних) докладний звіт щодо результатів. Підставою для автоматизованого висновку щодо значущості або незначущості кожного зі стимулів $є$ сукупність неконтрольованих свідомістю вазомоторних реакцій респондента, що суттєво відрізняється в залежності від того, як сприймається те чи інше слово крізь призму особистісного досвіду.

\section{Методику виявлення неусвідомлюваної перцептивно-мнестичної фіксації} субсенсорних стимулів шляхом пригадування розроблено нами як додатковий простий, апаратно-незалежний спосіб підтвердження ефекту слідової значущості субсенсорних слів, тобто ефектів підпорогового сприйняття, мимовільного i неусвідомлюваного запам'ятовування та подальшої ретенції таких слів в пам'яті. Надалі це явище називатимемо ефектом перцептивно-мнестичної фіксації субсенсорних стимулів. Методика підтвердження зазначеного ефекту шляхом пригадування грунтується на тому факті, що під час методики формування субсенсорного 
стимула ніхто з досліджуваних не зміг розпізнати хоча б два слова 3 першої спроби, на частоті 120 кадрів на секунду (експозиція 8,3 мс). Це означає, що спроб завжди було щонайменше дві. 3 цього, в свою чергу, випливає, що протягом експерименту досліджувані бачили набагато більше слів, ніж свідомо розпізнали та назвали уголос. I хоча субсенсорним стимулом, як показано вище, вважалося лише одне слово, - для підкріплення демонстроване досліджуваному двічі і все одно їм не розпізнане, - насправді такими стимулами могли також виявитися будьякі слова з попередніх спроб. Правомірно було очікувати, що 3 масиву надрукованих на папері слів досліджуваний може згадати та упізнати не тільки ті слова, котрі він впевнено називав, але й субсенсорні, тобто такі, які він бачив, але не встиг розпізнати. Отже, досліджуваному надавався аркуш паперу з усіма надрукованими словами-стимулами (гарнітура друку була такою ж самою, якою слова-стимули раніше виводилися на екран), де він мав підкреслити всі слова, котрі раніше з'являлися на екрані в тахістоскопічному експерименті розпізнавання.

Процедура дослідження починалася 3 того, що людину просили зосередити увагу в центрі екрану і спробувати прочитати всі три слова, які там 3'являться на одну мить. Якщо це не вдавалося, спробу повторювали 3 іншими словами та дещо більшим часом експозиції стимулів. Досліджуваного інструктували називати вголос будь-яке слово, яке він побачить, навіть якщо в нього не буде повної впевненості в правильності прочитування. Таким чином, стимульні серії завжди демонструвалися в порядку від мінімально можливої експозиції (8,3 мс) до більш тривалої, тобто від складніших умов сприйняття до спрощених. Експеримент призупинявся на тій спробі, де досліджуваний правильно прочитав два стимульних слова 3 трьох. Цей фрагмент демонструвався ще раз, i якщо досліджуваний знову не міг назвати третє слово (що i спостерігалося в абсолютній більшості випадків), це нерозпізнане слово можна було впевнено вважати субсенсорним стимулом, адже воно двічі побувало в полі зору i не було ідентифіковано досліджуваним. В тих поодиноких випадках, коли досліджуваний в повторній спробі називав всі три слова, експеримент починали наново з іншими серіями.

Після формування субсенсорного стимула проводилася, за допомогою цифрового реографа «Реоком-стресс», описана вище методика психофізіологічного оцінювання реакції на цей стимул в порівнянні з вазомоторними реакціями на «слова-пустушки» i на два усвідомлено розпізнаних стимульних слова. Через 25-30 хвилин, зайнятих іншою активністю, досліджуваного просили «просто підкреслити на бланку всі слова, які раніше з'являлися на екрані під час швидкої демонстрації слів». Зрештою, заключним етапом дослідження була повторна процедура поліграфічного підтвердження значущості субсенсорного стимула. Загальна тривалість одного індивідуального дослідження варіювала в межах 30-60 хвилин, залежно від ступеня загальмованості паціснта.

Результати апробації розробленого комплексу експериментально-психологічних методик полягають в наступному. Порівняння порогових значень між групами здорових осіб та хворих на афективні розлади показало, що суттєво відрізняється лише перший поріг, тобто експозиція розпізнавання першого (якогось одного) слова. У здорових цей показник дорівнює $13,72 \pm 6,38$ мс, у хворих він складає 47,36 $\pm 64,02$ мс $(p<0,05)$. Інакше кажучи, хворі потребують більш ніж втричі тривалішої експозиції стимулів, ніж здорові, аби розпізнати хоча б одне слово з трьох. Дисперсія, знову-таки, вдесятеро більше у хворих.

Далі, загалом по вибірці було виявлено значущу лінійну кореляцію між зоровим сенсорним порогом та віком досліджуваних $(\mathrm{r}=0,370, \mathrm{p}<0,05)$, тобто чим старшою є людина, тим важче їй впізнати швидко демонстроване слово. Втім, більш детальний аналіз показав, що цей кореляційний зв'язок не спостерігається в контрольній групі (p>0,05). Отже, залежність порогів розпізнавання від віку достовірно модерується таким фактором, як наявність афективних порушень, і особливо це стосується пацієнтів 3 тривожно-депресивними розладами $(\mathrm{r}=0,620, \mathrm{p}<0,05)$. 
Детекція значущості субсенсорних стимулів за допомогою апаратно-програмного комплексу «Реоком-стресс» показала, що аномально сильна реакція на зафіксовані раніше субсенсорні стимули знайшла підтвердження на психофізіологічному рівні у 32 (84,21\%) осіб з 38 обстежених. В абсолютній кількості випадків значущість субсенсорного стимула поєднувалася 3 констатацією значущості свідомо розпізнаних слів. Проще кажучи, досліджувані реагували на субсенсорний стимул так само, як і на ті слова, котрі залишилися в пам'яті правильно прочитаними та ідентифікованими. Не можна не звернути увагу також на той факт, що ефект мимовільної перцептивно-мнестичної фіксації в негайному реографічному дослідженні (безпосередньо після тахістоскопічної методики формування субсенсорного стимула) підтвердився у 15 (100\%) здорових осіб, але лише у 17 з $23(73,91 \%)$ пацієнтів з афективними розладами.

Також встановлено наявність достовірно сильної зворотньої кореляції між порогами сприйняття i кількістю розпізнаних стимулів негативного забарвлення $(\mathrm{r}=-0,6, \mathrm{p}<0,01)$. Цей результат певною мірою перекликається 3 класичними здобутками школи New Look, адже він означає, що розпізнавання стимулів 3 негативним емоційним забарвленням потребує більш тривалої експозиції. Проте важливим уточненням $€$ те, що виявлена кореляція набагато сильніша в основній групі хворих 3 емоційними порушеннями (де $\mathrm{r}=-0,620, \mathrm{p}<0,01$ ), ніж в контрольній групі здорових ( $\mathrm{r}=-0,378, \mathrm{p}>0,05)$. Інакше кажучи, саме пацієнтам 3 депресивними та тривожно-депресивними розладами притаманна неусвідомлювана тенденція «видивлятися» насамперед стимули 3 позитивним психосемантичним навантаженням, і в останню чергу упізнавати слова 3 негативним сенсом.

Стосовно процесів мимовільного запам'ятовування та відкладеного пригадування субсенсорних стимулів важливо зазначити, що в загальній кількості слів, пригаданих та підкреслених досліджуваними через 25-30 хвилин після тахістоскопічних демонстрацій, лише 49,38 відсотків прийшлося на частку тих слів, що раніше були правильно розпізнані й названі в тахістоскопічній методиці. 26,54\% пригаданих слів виявилися субсенсорними стимулами (тобто такими, які раніше були побачені, але не розпізнані), i, нарешті, 24,08\% слів являли собою хибні, парамнестичні згадки. Щодо частоти пригадування того єдиного слова, перцептивно-мнестична фіксація якого в методиці формування субсенсорного стимула була підкриплена щонайменше дворазовою демонстрацією, то цей ефект зареєстровано у 41,94\% досліджуваних, що значно перебільшує вірогідність випадкового угадування $(\mathrm{p}>0,01)$.

Загалом, у той чи інший спосіб, - негайним або відстроченим реографічним дослідженням, в методиці пригадування або в поєднанні з нею, підтвердження значущості субсенсорних стимулів здобуто для всіх 38 (100\%) спостережень. На нашу думку, викладене однозначно та переконливо підтверджує (причому не опосередкованими психодіагностичними, як в переважній більшості досліджень аналогічної спрямованості, а прямими, тобто психофізіологічними доказами) існування ефекту мимовільної перцептивномнестичної фіксації вербальних стимулів, експонованих з підпороговою експозицією.

\section{Висновки}

Розроблено комплекс експериментальнопсихологічних методик, який склали три нові методики: a) методика формування субсенсорного стимула; б) методика психофізіологічного підтвердження значущості субсенсорного стимула та в) методика виявлення неусвідомлюваної перцептивно-мнестичної фіксації субсенсорних стимулів шляхом пригадування. Комплекс призначено для дослідження і об'єктивізації характеристик швидкоплинних перцептивно-інформаційних процесів, що відбуваються на усвідомлюваному та неусвідомлюваному рівнях. Результати апробації переконливо свідчать про досить високу чутливість, інформативність i диференцюючу здатність застосованого підходу, що дозволяє в перспективі використовувати його 
як у науково-дослідницьких, так і у клінікодіагностичних цілях.

\section{Література}

PeoKoм-Stress для Windows XP. (2012). Компьютерная система оценки динамики изменения функционального состояния человека: Инструкция по эксплуатации. Наииональный аэрокосмический университет «ХАИ», НТЦ радиоэлектронных медииинских приборов и технологий «ХАИ-МЕДИКА», pp. 110.

Шестопалова, Л. Ф., Лінський І. В., Бородавко, О. О., Денисенко, М. М. (2015). Особливості сприйняття підпорогових візуальних вербальних стимулів з різним рівнем емоційної значущості. Психіатрія, наркологія та медична психологія, 2(1), 109-114.

Шестопалова Л.Ф., Луцик В.Л. (2020). Особливості сприйняття вербальної інформації у хворих на депресивні розлади. О.А. Панченко (ред.) Медикопсихологічні та інформаційні аспекти реабілітації $i$ абілітації людини, с. 322-324. Київ: КВІЦ.

Maruta, O. (2020). Adaptive potential of patients with mental disorders. Журнал психологічного консультування та nсихотерапіï, 13, 43-50.

Шестопалова Л.Ф., Бородавко О.А., Бучок Ю.С. (2019). Доверие как фактор формирования терапевтического альянса между врачом и пациентом. Психиатрия, психотерапия и клиническая психология, 10(4), 758-764.

\section{DEVELOPMENT AND TESTING OF EXPERIMENTAL PSYCHOLOGICAL TECHNIQUES FOR THE STUDY OF UNCONSCIOUS VISUAL-PERCEPTUAL PROCESSES}

Shestopalova Liudmyla

State Institution «Institute of Neurology, Psychiatry and Narcology of the National Academy of Medical Sciences of Ukraine» ac. Pavlov street 46, Kharkiv, 61068, Ukraine

Lutsyk Volodymyr

State Institution «Institute of Neurology, Psychiatry and Narcology of the National Academy of Medical Sciences of Ukraine» ac. Pavlov street 46, Kharkiv, 61068, Ukraine

The work is devoted to the actual problem of research of visual-perceptual processes that take place on an unconscious level. There is a shortage of reliable and informative psychodiagnostic tools, specially designed to study unconscious perceptual and mnestic phenomena in mentally healthy people and in the persons with affective disorders. It is emphasized that when creating such techniques, it is necessary to take into account the influence of emotional disorders on the course of basic mental processes. Three new experimental psychological techniques have been developed, aimed at research and objectification of transient conscious and unconscious perceptual-informational processes. The technique of forming a subsensory stimulus is a step-by-step determination of the exact threshold time of exposure, in which one verbal stimulus out of three demonstrated ones remains unidentified at the conscious level, i.e. subsensory. The technique of psychophysiological confirmation of the significance of a subsensory stimulus is an automated registration-analytical procedure, which involves the use of a serial digital polygraph "Rheocom-stress" and allows you to identify the words most significant to the subject, regardless of the level of subjective awareness of that significance. The technique of detecting unconscious perceptual-mnestic fixation of subsensory stimuli is a method of studying the effect of involuntary memorization, retention and reproduction of subsensory stimuli. Approbation of the developed experimental psychological techniques was performed on the sample of 38 people, including 23 patients with affective disorders and 15 mentally healthy people. It is shown that the thresholds of visual perception in patients with affective disorders are almost three times higher than in the control group. The effect of perceptualmnestic fixation was confirmed by one or more methods in $100 \%$ of the cases. The results of the approbation conclusively testify to the high sensitivity and informativeness of the approach used.

Key words: experimental psychological techniques, visual perception, subthreshold perception, unconscious processes, subsensory stimuli, involuntary memorization, perceptual-mnestic fixation. 